\title{
EFFECT OF ACTIVITIES, LEARNING INTEREST, AND SELF-DIRECTED LEARNING TOWARD THE LEARNING OUTCOMES OF PHYSICS
}

\author{
ILYAS \\ Lecturer at the University of Jabal Ghafur, Sigli Aceh \\ ilyas.daud.1965@gmail.com
}

\begin{abstract}
The purpose of this research was to determine whether there is a direct effect of the activity of students in learning, learning interest, and the self-directed learning to the learning outcomes of physics.

The method used is causal path analysis. Causal research conducted to describe the scheme and effect relationship that is deeper than two or more of the facts and the properties of the subject under research. The sample in this research was 156 students were randomly selected as a research subject. Data collection techniques used are questionnaires and tests. Data processing techniques using path analysis. The results showed that: (1) the activity of students in learning directly affects learning outcomes physics, (2) the interest of student learning directly affects learning outcomes physics, (3) the independence of student learning directly affects learning outcomes physics, (4 ) students in learning activities directly affect student learning independence, (5) interest in learning directly affects learning independence (6) students in learning activities directly affect the interest in learning.

The implications of this research indicate that the activities, interests and independence of learning can be enhanced so as to affect the outcome of learning physics
\end{abstract}

Keywords: student activities, learning interest, self-directed learning, learning outcomes

\section{PENGARUH AKTIVITAS, MINAT BELAJAR DAN KEMANDIRIAN BELAJAR SISWA TERHADAP HASIL BELAJAR FISIKA}

\begin{abstract}
ABSTRAK
Tujuan penelitian ini adalah untuk mengetahui pengaruh aktivitas siswa dalam pembelajaran, minat belajar, dan kemandirian belajar terhadap hasil belajar fisika siswa kelas XI SMA Negeri 1 Sigli, Aceh.

Metode penelitian yang digunakan adalah kausal dengan path analysis (analisis jalur). Penelitian dilakukan untuk menggambarkan skema hubungan dan pengaruh yang lebih dalam dari dua atau lebih fakta-fakta dan sifat-sifat subjek yang diteliti. Adapun Instrumen yang digunakan berupa kuesioner dan tes, sedangkan yang menjadi sampel adalah 156 siswa yang diambil secara random sebagai subjek penelitian. Teknik pengolahan data menggunakan path analisis. Hasil penelitian menunjukkan bahwa : (1) aktivitas siswa dalam pembelajaran pengaruh secara langsung terhadap hasil belajar fisika, (2) minat belajar siswa berpengaruh secara langsung terhadap hasil belajar fisika, (3) kemandirian belajar siswa berpengaruh secara langsung terhadap hasil belajar fisika, (4) aktivitas siswa dalam pembelajaran berpengaruh secara langsung terhadap kemandirian belajar siswa, (5) minat belajar siswa berpengaruh secara langsung terhadap kemandirian belajar siswa (6) aktivitas siswa dalam pembelajaran berpengaruh secara langsung terhadap minat belajar siswa.

Implikasi dari penelitian ini menunjukkan bahwa aktivitas, minat belajar dan kemandirian belajar dapat ditingkatkan sehingga dapat mempengaruhi hasil belajar fisika
\end{abstract}

Kata kunci: aktivitas siswa, minat belajar, kemandirian belajar, hasil belajar

\section{PENDAHULUAN}

Lembaga pendidikan merupakan institusi penting bagi proses penyiapan dan peningkatan kualitas sumber daya manusia Indonesia yang benar-benar berkualitas.Secara garis besar ada empat masalah utama yang berkaitan dengan kualitas pendidikan nasional di Indonesia, yaitu kesenjangan pengetahuan (knowledge gap), 
rendahnya kualitas sumber daya manusia (SDM), penurunan moral dan persoalan disintegrasi bangsa.

Pertama, kesenjangan pengetahuan, hal ini diakibatkan oleh dimanjanya siswa oleh guru saat ujian nasional (UN) yang hampir rata-rata daerah membantu siswa saat ujian dengan memberikan kunci jawaban kepada siswa, ini sesuatu hal yang luar biasa yang perlu dibasmi sampai keakar-akarnya. Kedua, adalah kualitas sumber daya manusia sebagai output pendidikan yang kurang memadai, hal ini dapat kita lihat bersama pada saat anak mau ikut tes Ujian Masuk Perguruan Tinggi Negeri (USMU/SPMB) dan apapun namanya, orang tua lebih percaya pada bimbingan tes yang sifatnya sesaat ketimbang anaknya diajarkan di sekolah bertahun-tahun. Ketiga, rendahnya kualitas moral bangsa, hal ini jelas-jelas sekali kelihatan yang selalu diisukan dengan kenakalan remaja, pada hal kenakalan orang tua tidak ada yang mau peduli. Orang tua sudah berguru pada siswa, dulu tawuran antar pelajar dan siswa, sekarang tawuran antar warga, kampus dan sekolah jadi lahan penjualan psikotropika. Keempat, disintegrasi bangsa seperti yang dipicu oleh konflik antar suku, adat, ras dan agama. Ini semuanya disebabkan oleh lembaga pendidikan tidak mampu melahirkan bangsa yang memiliki wawasan kebangsaan sebagai identitas nasional yang ditandai oleh kecintaan terhadap tanah air.

Apabila dicermati dari berbagai tuntutan baik dasar maupun perkembangannya, maka penyelenggara pendidikan dituntut untuk lebih mengantisipasi tuntutan tersebut, paling tidak pendidikan diharapkan mampu mengikuti perubahan zaman yang terjadi.

Keberhasilan meningkatkan sumber daya manusia sekarang ini tampaknya bukan hasil dari pendidikan yang diharapkan, akan tetapi hasil dari pendidikan itu adalah menghasilkan potensi masing-masing individu yang nantinya mampu mandiri. Karena peserta didik diharuskan kreatif, inovatif dan produktif yang berguna bagi masyarakat.

Dengan demikian, kualitas dan produktivitas pembelajaran akan tampak pada seberapa jauh siswa mampu mencapai tujuan pembelajaran yang telah dirancang oleh guru.Hal ini menunjukkan bahwa untuk mencapai kualitas dan produktivitas pembelajaran yang lebih baik, maka materi pelajaran harus dikemas, dikelola dan diorganisir melalui metode penyampaian yang tepat. Oleh karena itu salah satu tugas dari guru adalah bagaimana menyelenggarakan pembelajaran seefektif mungkin.

Hasil survey terbatas yang peneliti lakukan terhadap siswa SMA Negeri 1 Sigli pada tahun 2015, menunjukkan bahwa siswa masih sulit memahmi pelajaran fisika. Hasil belajar mata pelajaran fisika siswa kelas XI SMAN 1 Sigli tahun pelajaran 2015 rata-rata 6,3 atau dibawah standar minimal nasional 6,5.

Ketidakpuasan terhadap perolehan hasil pelajaran fisika ini diduga dipengaruhi oleh beberapa faktor, yakniadanya perbedaan individual dalam diri siswa yang akan mempengaruhi minat atau motivasi untuk belajar. Perbedaan individual ini ada yang bersifat internal seperti tingkat kecerdasan, minat, efikasi diri, gaya kognitif, locus of control yang terkait dengan motivasi belajar,disiplin belajar, kemandirian belajar, gaya belajar, dan motivasi belajar.

Adanya minat untuk belajar dalam diri seseorang dapat mendorong semangat, gairah, keaktifan, dan kesungguhannya terhadap objek yang dipelajari.Keberhasilan belajar siswa dapat dilihat dari minat belajar yang dimilikinya. Selain minat belajar, faktor lain ada dalam diri siswa yang mempunyai peran cukup dominan terhadap cara belajar siswa adalah efikasi diri yang dimiliki oleh siswa, yaitu bagaimana seseorang meyakini bahwa ia mampu menguasai materi yang diajarkan.Kondisi ini akan menimbulkan semangat dalam dirinya untuk mendapatkan hasil belajar yang lebih baik.

Hasil belajar yang diharapkan dalam suatu proses pembelajaran menurut Anderson (2010:41)antara lain adalah peserta didik mempunyai suatu kompetensi tertentu yang mencakup tiga ranah dalam proses pembelajaran, yaitu; ranah kognitif, ranah afektif, dan ranah psikomotor.Namun hasil belajar yang diukur dalam penelitian ini ditekankan pada ranah kognitif saja.Hasil belajar tersebut diacukan pada domain kognitif menurut taksonomi Bloom revisi Anderson (2010:43) yang meliputi: (1) mengingat, (2) memahami, (3) mengaplikasikan, (4) analisis, (5) evaluasi, dan (6) mencipta.

Aktivitas, dalam mengikuti proses pembelajaran, sangat menentukan hasil belajar siswa, terutama aktivitas siswa dalam mengikuti proses belajar mengajar. Dalam beraktivitas, siswa tidak hanya mendengar dan mencatat seperti yang sering dijumpai 
disekolah-sekolah tradisonal. Diendrich (dalam Sardiman, 2005:101) membuat suatu daftar yang berisi 177 macam kegiatan siswa, yang dapat digolongkan antara lain sebagai berikut: (a) Visual activities, yang termasuk didalamnya misalnya misalnya: membaca, memperhatikan gambar demonstrasi, percobaan, pekerjaan orang lain; (b) Oral activities, seperti: menanyakan, meneruskan, bertanya, memberi saran, mengeluarkan pendapat, mengadakan wawancara, diskusi, interupsi; (c) Listening activities, sebagai contoh: mendengarkan, uraian, percakapan, diskusi, musik, pidato; (d) Writing activities, seperti: menulis cerita, karangan, laporan, angket, menyalin; (e) Drawing activities, misalnya: menggambar, menggambar grafik, peta diagram; (f) Motor activities, yang termasuk didalamnya: melakukan percobaan, melakukan konstruksi, mereparasi model, bermain, berkebun, beternak; (g) Mentalactivities, misalnya: menggali, mengingat, memecahkan soal, menganalisis, melihat hubungan, mengambil keputusan; (h) Emotional activities, misalnya: menaruh minat, merasa bosan, gembira, bersemangat, bergairah, berani, tenang, dan gugup.

Dalam proses pembelajaran siswa dituntut untuk lebih aktif karena pada prinsipnya belajar adalah suatu pembelajaran. Dalam proses belajar siswa harus melakukan sesuatu untuk mengubah tingkah laku (dari yang tidak bisa menjadi bisa atau dari yang belum mengerti menjadi lebih mengerti) sebagai aktivitas dalam proses pembelajaran. Aktivitas siswa dalam pembelajaran merupakan unsur yang sangat penting dalam mengembangkan potensi yang ada pada dirinya. Proses pembelajaran dikatakan efektif apabila siswa secara aktif ikut terlibat langsung dalam pengorganisasian dan penemuan informasi (pengetahuan) sehingga mereka tidak hanya menerima secara pasif pengetahuan yang diberikan oleh guru tetapi lebih berminat untuk mempelajarinya.

Minat erat hubungannya dengan dorongan (drive), motiv dan reaksi emosional. Misalnya berminat terhadap riset ilmiah, maka bisa timbul tindakan atau terangsang oleh keinginannya untuk merasa ingin tahu terhadap kegiatan tersebut.Minat dapat dikatakan sebagai motivasiapabila siswa menunjukan arah perhatian terhadap objek yang menarik atau menyenangkannya. Apabila individumemperhatikan suatu objek yang menyenangkan, maka ia akan cenderung berusaha aktif untuk mengetahui tentang objek tersebut.

Faktor yang terpenting dalam membangkitkan minat adalah pemberian kesempatan bagi siswa untuk aktif berpartisipasi dalam kegiatan belajar. Seiring dengan pengalaman belajar yang menimbulkan kebahagiaan, minat anak akan terus tumbuh. Apabila anak memperoleh keterikatan kepada kegiatan-kegiatan dari pelajaran yang dialaminya, ia akan merasa senang. Oleh karena itu minat terhadap pelajaran harus ditimbulkan dalam diri anak, sehingga anak terdorong untuk mempelajari berbagai ilmu yang ada di kurikulum sekolah, utamanya pelajaran fisika.

Anak yang mandiri cenderung ingin melepaskan ketergantungan dan kontrol dari orang lain. Slavin (1994:15) menyatakan, They try to establish their independence from adult control. Mereka mencoba membentuk kemandirian atau melepaskan ketergantungan dari orang tua. Untuk mencapai tujuan tersebut, satu-satunya jalan yaitu dengan belajar.

Orang yang berjiwa mandiri dapat menentukan pilihan sendiri secara bertanggung jawab kapan ia mau belajar atau ia mau belajar apa. Seperti pendapat Alder (2001:6), "semuanya selalu diawali dengan sebuah keputusan. Kita tidak perlu otak yang jenius untuk mengambil suatu keputusan. Kita hanya memerlukan akal sehat dan sedikit pengetahuan praktis yang bisa Anda petik dan terapkan seiring dengan perjalan hidup Anda. Anda mempunyai pilihan untuk mengetahui dan menggunakan pikiran Anda semaksimal mungkin".

Esensi kemandirian belajar yaitu adanya aktivitas belajar yang diatur oleh diri sendiri, kesadaran sendiri, dan bersifat mandiri. Brookfield (1996:48) mengatakan "selfdirected learning that stress the outonomous orindependent nature of such learning". Belajar mandiri menekankan pada pengaturan kebutuhan sendiri atau sifat kemandirian dalam belajar.

Kemandirian memiliki lima komponen utama, yaitu:1) Bebas, yakni tumbuhnya kegiatan atas kehendak sendiri dan bukan karena orang lain, bahkan tidak tergantung pada orang lain; 2) Progresif dan ulet, seperti tampak pada mengejar prestasi, penuh ketekunan, merencanakan, dan mewujudkan harapan-harapan; 3) Berinisiatif, yakni mampu 
berpikir dan bertindak secara orisinal, kreatif, dan penuh inisiatif; 4) Pengendalian diri dari dalam (internal locus of control), yakni kemampuan mengatasi masalah yang dihadapi, mampu mengendalikan tindakannya serta kemampuan mempengaruhi lingkungan atas usahanya sendiri, dan 5) Kemantapan diri (selfesteem, self-confedence), mencakup aspek percaya kepada diri sendiri dan memperoleh kepuasan atas usaha sendiri.

Penelitian ini secara umum bertujuan untuk membuktikan pengaruh lansung positif aktivitas siswa, minat belajar, kemandirian belajar siswaterhadap hasil belajar fisika.

\section{METODOLOGI PENELITIAN}

Penelitian ini dilaksanakan di SMAN I Sigli pada kelas XI semester II, jurusan IPA. Dalam penelitian ini digunakan metode kausal dengan path analysis (analisis jalur). Penelitian kausal dilakukan untuk menggambarkan skema hubungan dan pengaruh yang lebih dalam dari dua atau lebih fakta-fakta dan sifat-sifat subjek yang diteliti.Analisis data digunakan teknik korelasi dan regresi dan sebelumnya terlebih dahulu dilakukan uji persyaratan. Menurut Sudjana (1992:466-468), untuk menguji hipotesis terlebih dahulu dilakukan uji persyaratan, yaitu uji normalitas diuji dengan Lilliefors, dan uji linieritas sebagai uji lanjut.

Penelitian ini mengkaji keterkaitan antar variabel yang diteliti berdasarkan fakta dan data serta mengukur pengaruh satu variabel terhadap variabel lainnya. Variabel bebas adalah aktivitas siswa dalam pembelajaran (X1), minat belajar (X2) dan kemandirian belajar (X3), sedangkan variabel terikat adalah hasil belajar fisika (X4).

Pengumpulan data aktivitas siswa dalampembelajaran, minat belajar dan kemandirian belajar siswa dilakukan dengan menggunakan kuesioner. Sedangkan untuk data hasil belajar fisika dilaksanakan tes tertulis dalam bentuk

pilihan ganda. Alasan penggunaan tes pilihan ganda adalah agar terwakili semua materi pelajaran pada semester dua.

\section{HASIL PENELITIAN DAN PEMBAHASAN}

Adapun deskripsi data yang berhubungan dengan variabel-variabel yang diteliti, yaitu variabel terikat dalam penelitian ini adalah hasil belajar fisika (X4), sedangkan yang menjadi variabel bebas adalah aktivitas siswa dalam pembelajaran (X1), minat belajar siswa (X2) dan kemandirian siswa dalam belajar (X3). Deskripsi masing-masing variabel secara berturut-turut disajikan mulai dari variabel $\mathrm{X} 1, \mathrm{X} 2, \mathrm{X} 3$, dan $\mathrm{X} 4$ dalam tebel berikut ini.

\section{DESKRIPSI HASIL PENELITIAN}

\begin{tabular}{|c|c|c|c|c|c|}
\hline 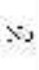 & $\begin{array}{l}\text { Lubros: } \\
\text { Stristik }\end{array}$ & $\frac{\text { Astivitas }}{(\mathrm{X} 1)}$ & $\begin{array}{l}\text { Mind } \\
(\mathrm{A} i)\end{array}$ & $\begin{array}{c}\text { Kuzunaditian } \\
(\mathrm{x} S)\end{array}$ & $\begin{array}{c}\text { Exsil } \\
\text { Bıllajat } \\
\text { (X1j }\end{array}$ \\
\hline 1 & Danys totireci: & 96 & 12 & 33 & 16 \\
\hline 2 & 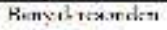 & 1.56 & $15 \%$ & 156 & 356 \\
\hline 3 & Jun'zhakor & 21.197 & 18.957 & 19.659 & 2.392 \\
\hline 1 & Vilai ringrimatar & 37 & Q प. & 84 & 10. \\
\hline 5 & Filai moks artn & 176 & 153 & .81 & 24 \\
\hline 6 & lons: & 89 & $\infty$ & 3) & 14 \\
\hline 7 & dho ble inlogral & 20 & 7 & 8 & 2 \\
\hline 8 & Tyt ls irtevil & 9 & $y$ & 9 & 9 \\
\hline ب & Xecia & 35.878 & 121,712 & 125,891 & $15,313.3$ \\
\hline 20 & Xstiar. & 236.400 & 20,000 & 156,000 & 15.000 \\
\hline 11 & Vodins: & $\therefore 6,200$ & 216,000 & 127,000 & 11.900 \\
\hline 12 & S:ataca: driesi & 74.580 & 11,652 & 12,704 & 3,279 \\
\hline 13 & & $212,59=$ & $13 \leq, 76 s$ & 161,101 & 10.727 \\
\hline
\end{tabular}

Pengujian normalitas dilakukan dengan menggunakan uji Lilliefors dimana hipotesis yang diuji adalah hipotesis nol yang menyatakan bahwa sampel-sampel berasal dari populasi yang berdistribusi normal. Kriteria pengujian Ho diterima bila harga Lo (Lhitung)< L (Ltabel), berarti populasi berdistribusi normal. Hasil-hasil pengujian uji normalitas dapat dilihat dalam rangkuman tabel di bawah ini.

Galat

Rangkuman Hasil Pengujian Normalitas

\begin{tabular}{|c|c|c|c|c|c|}
\hline \multirow{3}{*}{$\begin{array}{l}\text { No } \\
1\end{array}$} & \multirow{3}{*}{$\begin{array}{c}\text { Cislat Taksirm } \\
\text { Reztesi } \\
\text { X, nas X. }\end{array}$} & \multirow{3}{*}{ N } & \multicolumn{2}{|c|}{$1 \mathrm{w}$} & \multirow{3}{*}{$\begin{array}{l}\text { Kxomniagn } \\
\text { Ser Jistribus: } \\
\text { Dornan! }\end{array}$} \\
\hline & & & Itrever & 1) & \\
\hline & & & $9 x<5$ & 0.002 & \\
\hline 2 & X: rlats X; & $1.5 \%$ & 7, $1 x^{6}$ if & 0,11709 & $\begin{array}{l}\text { Fortiatrikns } \\
\text { tomnal }\end{array}$ \\
\hline 3 & $\mathrm{X}_{\mathrm{L}} \operatorname{ctas} \mathrm{X}_{3}$ & 156 & $2,0<7 \%$ & 0.0709 & $\begin{array}{l}\text { 3en fistribus: } \\
\text { jormn! }\end{array}$ \\
\hline 4 & $\mathrm{X}_{2}$ itas $\mathrm{X}_{2}$ & $1.5 \mathrm{~h}$ & tiprus & 0,11704 & $\begin{array}{l}\text { Fectiarcikes } \\
\text { |xrnuz| }\end{array}$ \\
\hline 2 & $X:$ tas $X$; & 156 & Jue: & $0,0,0 \%$ & $\begin{array}{l}\text { indifitikes } \\
\text { soment }\end{array}$ \\
\hline$\dot{n}$ & $\mathrm{X}_{\mathrm{S}}$, hlas $\mathrm{X}_{\mathrm{L}}$ & 1.56 & $\pi, 0<4:$ & 0,9703 & $\begin{array}{l}\text { Serfiatribus. } \\
\text { monnol }\end{array}$ \\
\hline
\end{tabular}

Sebelum menghitung koefisien jalur $(\beta)$ maka terlebih dahulu harus dihitung nilai koefisien korelasi dengan menggunakan rumus Produck Moment $\mathrm{r}_{x y}=$ $\frac{n \sum x_{i} y_{i}-\left(\sum x_{i}\right)\left(\sum y_{i}\right)}{\sqrt{\left.\left[n \sum x_{i}^{2}-\left(x_{i}\right)^{2}\right] \mid n \sum y_{i}^{2}-\left(y_{i}\right)^{2}\right]}}$ dan hasil perhitungannya seperti dalam tabel koefisien korelasi berikut ini. 
Tabel matrik koefisien korelasi antara $\mathrm{X}_{1}, \mathrm{X}_{2}, \mathrm{X}_{3}$ dan $\mathrm{X}_{4}$

\begin{tabular}{|c|c|ccc|}
\hline $\mathrm{r}_{\mathrm{z}}$ & $\mathrm{X}_{1}$ & $\mathrm{X}_{7}$ & $\mathrm{X}_{5}$ & $\mathrm{X}_{4}$ \\
\hline $\mathrm{X}_{\mathbf{*}}$ & 1,00 & 0,27 & 0,23 & 0,27 \\
\hline $\mathrm{X}_{2}$ & 0,17 & 1,07 & 0,73 & 0,34 \\
$\mathrm{X}_{5}$ & 0,23 & 0,33 & 1,00 & 0,38 \\
\hline $\mathrm{X}_{4}$ & 0,27 & 0,34 & 0,38 & 2,00 \\
\hline
\end{tabular}

\section{PENGUJIAN HIPOTESIS}

Setelah semua persyaratan terpenuhi maka analisis jalur dapat dilakukan. Model kausal yang dibentuk secara teoretik diperoleh d Diagram Jalur antara $\mathrm{X}_{1}, \mathrm{X}_{2}, \mathrm{X}_{3}, \mathrm{X}_{4}$

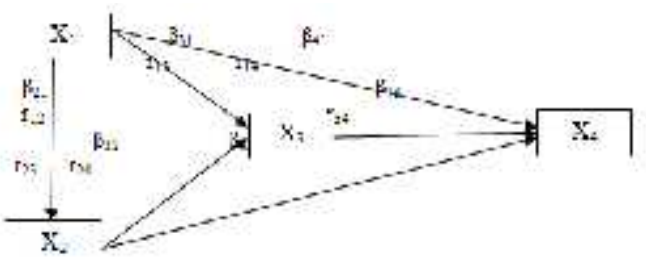

Diagram jalur seperti pada gambar di bawah ini.

Berdasarkan diagram jalur di atas diperoleh 6 (enam) buah koefisien jalur yang dilakukan analisis, yaitu: $\beta_{41}, \beta_{42}, \beta_{43}, \beta_{31}, \beta_{32}$ dan $\beta_{21}$ dengan $6(\mathrm{enam})$ buah koefisien korelasi, yaitu $r_{12}, r_{13}, r_{23}, r_{14}, r_{24}$ dan $r_{34}$. Hubungan antara koefisien korelasi $r_{i j}$ dan koefisien jalur $\beta_{\mathrm{ji}}$ adalah sebagai berikut:

$$
\begin{aligned}
& \mathrm{r}_{12}=\beta_{21} \\
& \mathrm{r}_{13}=\beta_{31}+\beta_{32} \mathrm{r}_{12} \\
& \mathrm{r}_{23}=\beta_{32}+\beta_{31} \mathrm{r}_{12} \\
& \mathrm{r}_{14}=\beta_{41}+\beta_{42} \mathrm{r}_{12}+\beta_{43} \mathrm{r}_{13} \\
& \mathrm{r}_{24}=\beta_{42}+\beta_{41} \mathrm{r}_{13}+\beta_{43} \mathrm{r}_{13} \\
& \mathrm{r}_{34}=\beta_{43}+\beta_{41} \mathrm{r}_{13}+\beta_{42} \mathrm{r}_{23}
\end{aligned}
$$

Berdasarkan hasil perhitungan koefisien korelasi di atas, maka langkah selanjutnya nilai jalur dapat dihitung.Mencari koefisien jalur $\beta_{21}$. Dengan rumus $r_{12}=\beta_{21}$, maka dengan memasukkan nilai-nilainya maka diperoleh nilainya adalah 0,17 .

Setelah mendapatkan masing-masing koefisien jalur, maka selanjutnya dilakukan pengujian terhadap hipotesis penelitian yang telah dibuat, yaitu :

1. Aktivitas siswa dalam pembelajaran $\left(\mathrm{X}_{1}\right)$ berpengaruh langsung terhadap hasil belajar fisika $\left(\mathrm{X}_{4}\right)$.

Dari perhitungan diperoleh nilai koefisien jalur $\beta_{41}=0,17$ dengan nilai $t_{\text {hitung }}=$ 3,48 pada taraf $\alpha=0,05$ diperoleh nilai $t_{\text {tabel }}$ $(0,05 ; 156)=1,96$. Karena $t_{\text {hitung }}>t_{\text {tabel }(\alpha=0,05)}$ yaitu
3,48 > 1,96, maka koefisien jalur signifikan atau $\mathrm{H}_{0}$ ditolak dan hasil perhitungan ini dapat dikatakan bahwa aktivitas siswa dalam pembelajaran $\left(\mathrm{X}_{1}\right)$ berpengaruh terhadap hasil belajar fisika $\left(\mathrm{X}_{4}\right)$ siswa Kelas XI SMA Negeri 1 Sigli.

Dalam hal ini Cole dan Chan (1994:256), mendefinisikan bahwa aktivitas belajar sebagai "anything that students are expected to do, beyond input through reading or listening, in order to learn, practice, apply, evaluate, or in any other way respond to curricular content". Menurut definisi ini aktivitas belajar mengandung kegiatan: lisan (oral activities) seperti menjawab pertanyaan atau berpartisipasi dalam diskusi, menulis (writing) seperti menulis jawaban singkat, melengkapi uraian, meringkas, atau perbuatan yang diarahkan untuk mencapai tujuan (goaldirected action) seperti melakukan pengamatan dan pemecahan masalah. Aktivitas dalam konsep ini tidak hanya terbatas dalam ruang kelas, tetapi juga termasuk aktivitas di luar kelas (membaca secara individual dan pekerjaan rumah), berkaitan dengan latar atau setting (aktivitas dalam kelas, kelompok kecil atau aktivitas individual), baik dibawah pengawasan guru ataupun aktivitas secara bebas untuk mencapai hasil belajar yang lebih baik.

2. Minat belajar siswa $\left(\mathrm{X}_{2}\right)$ berpengaruh langsung terhadap hasil belajar fisika $\left(\mathrm{X}_{4}\right)$.

Dari perhitungan diperoleh nilai koefisien jalur $\beta_{42}=0,22$ dengan nilai $t_{\text {hitung }}=$ 4,49 pada $\alpha=0,05$ maka nilai $t_{\text {tabel }}(0,05 ; 156)$ $=1,96$. Karena $\mathrm{t}_{\text {hitung }}>\mathrm{t}_{\text {tabel }(\alpha=0,05)}$ yaitu $4,49>$ 1,96, maka koefisien jalur signifikan atau $\mathrm{H}_{0}$ ditolak. Dari hasil perhitungan ini dapat dikatakan bahwa minat belajar siswa $\left(\mathrm{X}_{2}\right)$ berpengaruh terhadap hasil belajar fisika $\left(\mathrm{X}_{4}\right)$ siswa Kelas XI SMA Negeri 1 Sigli.

Crow dan Crow (1989:303-304), mengemukakan juga bahwa minat erat hubungannya dengan dorongan (drive), motiv dan reaksi emosional. Misalnya minat terhadap riset ilmiah, mekanika atau mengajar bisa timbul dari tindakan atau dirangsang oleh keinginannya dalam merasa ingin tahu seseorang terhadap kegiatan tersebut. Minat sebagai motiv yang menunjukan arah perhatian individu terhadap objek yang menarik atau menyenangkannya. Apabila individu memperhatikan suatu objek yang menyenangkan, maka ia akan cenderung berusaha aktif dengan objek tersebut 
3. Kemandirian belajar siswa (X3) berpengaruh langsung terhadap hasil belajar fisika (X4).

Dari perhitungandiperoleh nilai koefisien jalur $\beta 43=0,27$ dengan nilai thitung $=5,10$ pada $\alpha=0,05$ diperoleh nilai ttabel $(\alpha=0,05 ; 156)=1,96$. Karena nilai thitung $>$ ttabel yaitu 5,10 > 1,96, maka koefisien jalur signifikan atau H0 ditolak. Dari hasil perhitungan ini maka dapat dikatakan bahwa kemandirian belajar siswa dalam pembelajaran (X3) berpengaruh terhadap hasil belajar fisika (X4) siswa Kelas XI SMA Negeri 1 Sigli.

Hal ini sesuai dengan pendapat Cole dan Chan (1994:417) yang menjelaskan prinsip kemandirian belajar yaitu, Principles for enhancing individual goal-setting and planning, fostering learning strategis, self-monitoring and personal commitment to learning. Prinsip kemandirian belajar untuk menambah rencana dan menentukan tujuan sendiri, mengembangkan strategi belajar, mengontrol diri sendiri dan komitmen pribadi untuk belajar. Dengan demikian, kemandirian belajar akan mempengaruhi hasil belajar peserta didik. 4. Aktivitas Belajar Siswa Dalam Pembelajaran (X1) Berpengaruh Langsung Terhadap Kemandirian Belajar Siswa (X3).

Dari perhitungan diperoleh nilai koefisien jalur $\beta 31=0,18$ dengan nilai thitung $=2,94$ pada $\alpha=0,05$ diperoleh nilai ttabel $(\alpha=0,05 ; 156)=1,96$. Karena nilai thitung $>$ ttabel yaitu 2,94 >1,96, maka koefisien jalur signifikan atau H0 ditolak maka dapat dikatakan bahwa aktivitas siswa dalam pembelajaran (X1) berpengaruh langsung terhadap kemandirian belajar (X3) siswa kelas XI SMA Negeri 1 Sigli.

Aktivitas belajar pada diri siswa dapat terjadi apabila guru berusaha menciptakan situasi dan kondisi pembelajaran yang kondusif. Menurut dePoter (2001:24), menarik keterlibatan siswa dalam belajar, yang memungkinkan munculnya aktivitas belajar pada diri siswa, maka guru harus membangun hubungan dengan menjalin rasa simpati dan saling pengertian.

Anak yang mandiri dalam belajar selalu berusaha untuk memahami dengan cara sendiri tentang materi yang baru dipelajarinya, dengan sedikit bimbingan dari orang-orang yang membantunya. Ketergantungan terhadap bantuan orang lain tersebut akan dilepaskan secara perlahan sampai benar-benar ia merasa sudah bisa belajar secara mandiri. Jika guru sudah benar dalam mengarahkan aktivitas siswa dalam belajar, maka akan terlihat secara perlahan kemandirian belajar siswa secara nyata.

5. Minat Belajar Siswa (X2) Berpengaruh Langsung Terhadap Kemandirian Belajar Siswa (X3).

Dari perhitungan diperoleh nilai koefisien jalur $\beta 32=0,30$ dengan nilai thitung $=4,34$ pada $\alpha=0,05$ diperoleh nilai ttabel $(0,05 ; 156)=1,96$, maka koefisien jalur signifikan atau H0 ditolak. Dari hasil perhitungan ini dapat dikatakan bahwa minat belajar siswa (X2) berpengaruh lansung terhadap kemandirian belajar fisika (X3) siswa Kelas XI SMA Negeri 1 Sigli.

Minat memainkan peranan penting dalam kehidupan seseorang dan mempunyai dampak yang besar atas perilaku dan sikap seseorang. Pendapat yang sejalan juga diungkapkan oleh Anastasi (2007:29), yang menyatakan bahwa hakikat dan kekuatan minat dan sikap seseorang merupakan aspek penting dari kepribadian, dimana karakteristik ini secara materil mempengaruhi prestasi pendidikan, pekerjaan, hubungan antar pribadi, kesenangan yang didapatkan seseorang dari aktivitas waktu luang, dan fase-fase lainnya dari kehidupan sehari-hari. Namun dalam perkembangannya minat hanyalah sesuatu yang timbul dari sebuah permainan penting antara pengetahuan dan sikap dalam belajar dan perkembangan. Seorang siswa kalau sudah ada rasa minat dalam dirinya untuk mempelajari suatu mata pelajaran, maka siswa tersebut akan menempuh bermacam cara untuk bisa menguasai materi pelajaran itu.

6. Aktivitas Siswa Dalam Pembelajaran (X1)

Berpengaruh Langsung Terhadap Minat Belajar Siswa (X2).

Dari perhitungan diperoleh nilai koefisien jalur $\beta 21=0,17$ dengan nilai thitung $=4,34$ pada $\alpha=0,05$ diperoleh nilai ttabel $(0,05 ; 156)=1,96$, maka koefisien jalur signifikan atau H0 ditolak. Dari hasil perhitungan maka dapat dikatakan aktivitas belajar siswa dalam pembelajaran (X1) berpengaruh terhadap minat belajar fisika siswa (X2) Kelas XI SMA Negeri 1 Sigli.

Menurut Sukmadinata (1995:5-6), aktivitas terdiri dari; (1) kegiatan motorik meliputi segala kegiatan individu, jasmaniah, misalnya; berjalan, melompat, dan menulis, (2) kegiatan kognitif merupakan kegiatan individu yang berhubungan dengan pengalaman, 
pemahaman serta penyadapan tentang dunia luar, misalnya; mengindera, mengamati, dan berpikir, (3) kegiatan konatif yaitu kegiatan yang berkenaan motivasi atau dorongan untuk mencapai sesuatu kehidupan dimasa yang akan datang, dan (4) kegiatan afektif yaitu yang berkenaan dengan penghayatan suatu emosi atau perasaan tertentu.

Hasil perhitungan koefisien jalur dapat dilihat pada rangkuman tabel berikut ini. Hasil perhitungan dan pengujian koefisien jalur

\begin{tabular}{|c|c|c|c|c|c|}
\hline Varitel & $\begin{array}{l}\text { Kotisim } \\
\text { hondism }\end{array}$ & $\begin{array}{l}\text { Kotfisiet } \\
\text { jalte }\end{array}$ & $t_{T+m}$ & $4 \times=100100$ & Simpulan \\
\hline $3+1$ & 0,27 & 0.17 & $3.4 !$ & 1,75 & Toctisicn jelur sig. \\
\hline $3_{i}$ & 034 & 1,7 & 112 & 1,9 & Kot igrn j: lin ay \\
\hline i: & 038 & 2.27 & 510 & 195 & Keefisien,alhr:siz \\
\hline $3 i$ & 0,23 & 0.18 & 2.94 & 1,95 & Kectisicn jêrur sig. \\
\hline ?i: & 0,33 & [.9] & 111 & 19, & Kreigen j: In ay \\
\hline 3.1 & 9,17 & 0,27 & $2,-4$ & 1,95 & Kcetisien jatur sig. \\
\hline
\end{tabular}

keterbatasan dan kelemahan meskipun telah diupayakan secara maksimal dan seobjektif mungkin. Keterbatasan tersebut perlu dikemukakan sebagai pertimbangan dalam menginterpretasi dan menggeneralisasikan hasil penelitian yang telah dilaksanakan.

Pertama, penelitian ini hanya melibatkan 156 siswa kelas XI SMA Negeri 1 Sigli Kabupaten Pidie Provinsi Aceh. Jumlah sampel yang terbatas dan hanya dilakukan pada satu sekolah, maka berpengaruh pada keputusan yang dihasilkan. Hasil penelitian ini dapat digeneralisasikan pada sekolah lain apabila sekolah tersebut mempunyai karakteristik yang sama dengan sekolah dimana sampel diambil. Meskipun hipotesis penelitian telah diuji pada taraf signifikansi 0,05 , tetapi masih perlu diuji lebih lanjut pada sampel yang berasal dari karakteristik yang bervariasi.

Kedua, pendekatan penelitian ini memakai metode kuantitatif, dimana aspekaspek variabelnya adalah hasil belajar fisika, aktivitas siswa dalam pembelajaran, minat belajar siswa dan kemandirian belajar siswa. Pengumpulan data dilakukan denganmenggunakan instrumen yang dipakai untuk mengukur keempat variabel tersebut. Pada instrumen penelitian masih terdapat kelemahan walaupun telah dilakukan uji validitas dan realibilitas pada saat uji coba. Penelitian ini lebih kepada tanggapan siswa terhadap faktor-faktor yang mempengaruhi variabel-variabel ini. Kelemahan dalam pengisian instrumen adalah jawaban responden yang kurang hati-hati atau diisi secara asal- asalan sehingga sangat mempengaruhi pada analisis data.

Berkenaan dengan keterbatasan penelitian tersebut di atas, kepada penguna hasil temuan ini diharapkan dapat memanfaatkan keterbatasan ini sebagai bahan masukan untuk ditindaklanjutinya.

Berdasarkan pembahasan dari hasil penelitian, maka temuan penelitian ini menunjukan bahwa : (1) Aktivitas siswa dalam pembelajaran berpengaruh terhadap hasil belajar fisika; (2) Minat belajar siswa berpengaruh terhadap hasil belajar fisika; (3) Kemandirian belajar siswa berpengaruh terhadap hasil belajar fisika; (4) Aktivitas siswa dalam pembelajaran berpengaruh terhadap kemandirian siswa dalam belajar; (5) Minat belajar siswa berpengaruh terhadap kemandirian siswa dalam belajar; (6) Aktivitas siswa dalam pembelajaran berpengaruh terhadap minat belajar siswa.

Berdasarkan hasil temuan penelitian ini, maka dapat disimpulkan bahwa hasil belajar fisika dapat ditingkatkan melalui aktivitas siswa dalam pembelajaran, minat belajar siswa, kemandirian siswa dalam belajar. Oleh karena itu untuk meningkatkan hasil belajar siswa khususnya pelajaran fisika guru harus memperhatikan ketiga faktor di atas, yaitu (1) guru harus melibatkan siswa dalamproses pembelajaran, (2) guru harus meningngkatkan minat belajar siswa, dan (3) guru harus bisa mengarahkan siswa lebih mandiri dalam belajarnya.

Berdasarkan hasil penelitian maka dapat dikemukakan beberapa saran, yaitu (1) Kepada orang tua/wali siswa agar mengarahkan aktivitas anak selagi di rumah untuk belajar, juga untuk para guru saat siswa di sekolah lebih serius memperhatikan aktivitas siswa baik dalam proses pembelajaran maupun saat istirahat; (2) Untuk meningkatkan minat belajar siswa, orang tua sebaiknya memberi motivasi yang sifatnya mendidik yaitu dengan memfasilitasi kebutuhan belajar siswa. Sedangkan untuk guru sangat diharapkan memberi feedback pada setiap aktivitas yang dikerjakan siswa; (3) Kepada siswa diharapkan mempunyai konsep mandiri yang positif dalam belajar, pandai mengatur waktu dan memahami apa yang dipelajari di sekolah sehingga hasil belajarnya lebih baik; (4) Para manajemen sekolah selalu memberikan pandangan untuk memperbaiki kualitas pembelajaran pada sekolah yang dipimpinnya, sehingga para guru 
merasa diperhatikan dalam melaksanakan tugasnya; (5) Para peneliti yang lain agar mengkaji faktor-faktor atau variabel lain yang dapat mendukung hasil belajar siswa khususnya pelajaran fisika.

\section{DAFTAR PUSTAKA}

Alder,Harry.Boost Your Intelegence Pacu EQ dan IQ Anda, (terjemahan Christina Prianingsih), Jakarta: Penerbit Erlangga, 2001

Anastasi, Anne. Psychological Testing, $7^{\text {th }}$ ed. Alih bahasa oleh Robertus Hariono S. Imam, Jakarta: Prenhalindo, 2007

Anderson, Lorin W. dan David R. Krathwohl.A Taxonomy for Learning, Teaching and Assessing: A Revision of Bloom's Taxonomy of Educational Objective, New York: Addison Wesley Longman, Inc., 2010

Brookfild, Stephen D. Understanding and facilitating Adult Learning, California: Jossey-Bass, Inc., 1996

Cole, Peter G. and Lorna K.S. Chan, Teaching Principles and Practice $2^{\text {nd }} e d$. New York: Printice Hall, 1994
Crow,Lester D. and Alice Crow, Educational Psychology,(alih bahasa oleh Abd. Rachman Abror), Yogjakarta: Nur Cahaya ,1989

dePotter, Bobbi. Mark Raerdon dan Sarah Singer-Nounie. Terjemahan Ary Nilamsari. Quantum Teaching, Mempraktikkan Quantum Learning di Ruang-Ruang Kelas, Bandung: Kaifa, 2001

Sardiman. Interaction of Teaching and Learning and Motivation. P.T. King Grafindo Persada: Jakarta.2004

Slavin,Robert E.Educational Psychology Theory and Practice, Massacchustts: Allyn and Bacon a Divisin of Paramount Publishing, 1994

Sudjana, MetodaStatistika, Bandung: Tarsito, 1992

Sukmadinata, Nana S. Guru Dalam Proses Belajar Mengajar, Suara daerah No. 07. Th. XXIV Juli 1995. 